\title{
Central banking and the crisis. A comparison of the Federal Reserve and the European Central Bank measures, and the ECB's changing role in the EU economic governance system
}

\author{
Marcin Roman Czubala* \\ Mónica Puente Regidor ${ }^{* *}$
}

\section{ABSTRACT}

The European Central Bank (ECB) has received a lot of criticism for its too little, too late performance to ease market pressures during the economic crisis. At the same time, the ЕСв and the Federal Reserve (Fed) have managed the new economic realities that have emerged in the international context differently. Despite the criticisms, the European Central Bank is the European Union institution that has assumed more control due to the new model of economic governance of the EU.

Why did the Federal Reserve act so nimbly and quickly to calm the markets, while the ECB was so cautious in managing monetary policy? The aim of this paper is to perform a comparative analysis of the management of

\footnotetext{
* Máster en Política Internacional: Estudios Sectoriales y de Área. Investigador de la Facultad de Ciencias Políticas y Sociología, Universidad Complutense de Madrid, Madrid (España). mczubala@ucm.es

** Doctora en Ciencias Políticas y de la Administración. Investigadora de la Facultad de Ciencias Políticas y Sociología, Universidad Complutense de Madrid, Madrid (Espańa).mpuenter@cps.ucm.es
}

Recibido: 21 de agosto de 2015 / Modificado: 4 de octubre de 2015 / Aceptado: 6 de diciembre de 2015

Para citar este artículo

Czubala, M. R. y Puente Regidor, M. (2016). Central banking and the crisis. A comparison of the federal reserve and the European Central Bank measures, and the есв's changing role in the Eu economic governance system. OASIS, 23, 147-167. DOI: http://dx.doi.org/10.18601/16577558.n23.08 
interest rates and other monetary policy measures undertaken by the Central Bank and the Federal Reserve during the economic crisis, as well as to understand the changes in the context of the ЕСВ and the emergence of its authority within the European Union's economic governance model since 2011. Thus, in order to carry out a scrupulous exposition, we will also limit the time frame of this study to the 2007-2014 period.

Key words: European Central Bank, Federal Reserve, monetary policy, crisis, European Union

JEL Classification Codes: E58, F02, F15, F42

\section{El Banco Central y la crisis. Un análisis comparativo de las medidas tomadas por la Reserva Federal y el Banco Central Europeo, y el cambiante papel de la BCE en el sistema de gobernanza económica en la Unión Europea}

\section{RESUMEN}

Han sido múltiples las críticas que ha recibido el Banco Central Europeo (BCE) por sus actuaciones too little, too late en la crisis económica para aliviar las presiones de los mercados. El BCE y la Reserva Federal (FED) han gestionado la crisis siguiendo tiempos distintos. A pesar de estas críticas, el BCE es la institución comunitaria que más poder ha ganado en el nuevo modelo de gobernanza económica de la Unión Europea (UE).

¿A qué se debe que la Reserva Federal actuara de forma tan ágil y rápida para calmar a los mercados y el BCE haya sido tan cauto en su gestión de la política monetaria? El objetivo de este artículo es realizar un análisis comparativo de la gestión de los tipos de interés y otras medidas de política monetaria del BCE y la Reserva Federal durante la crisis económica, y que este nos ayude a entender mejor los cambios en el ámbito del Banco Central Europeo y la emergencia de su poder en el modelo de gobernanza económica de la Unión Europea a partir de 2011. Así, con el fin de proceder a un estudio más profundo, limitaremos el marco temporal de este al periodo 2007-2014.

Palabras clave: Banco Central Europeo, Reserva Federal, política monetaria, crisis, Unión Europea

Clasificación JEL: E58, F02, F15, F42

\section{INTRODUCTION}

In recent years, mainly since 2007 , central banks have started to play an exceptional role in public life as a result of the economic crisis, especially the Federal Reserve (Fed) and the European Central Bank (ЕСв). Before the crisis, it was usual for most parts of society not to know who the president of the ЕСв was. However, today many citizens do recognise Mario Draghi. Surprisingly, even those who are not specialists in the matter may also know Janet Yellen, the president of the Federal Reserve. From a European perspective, the case 
of the ЕСв and its president is an especially interesting one. We are not surprised that Mario Draghi's statements appeared in the news and the press, and even competed with nationally relevant stories within the time of broadcast. There is no doubt that the actions taken by the Federal Reserve and the European Central Bank have been present throughout the crisis, and therefore, so have the comments and the judgments about the responses that both central banks have articulated.

Since its first signs, the criticisms of the ECB's measures were constant. Although analysis of advanced data and warnings from international financial institutions indicated that the risk of the crisis expanding into Europe could have far-reaching consequences, while the Fed lowered its interest rates in mid-August 2007, the ЕСв decided to apply the same measure in October 2008. In other words, one year after the Federal Reserve's actions have been taken and when all the alarms have sounded. Only then did the institution that was entrusted with the management of monetary policy in the eurozone start to use the aforementioned instrument to respond to market concerns. The question must be asked, then, why did the Fed act so nimbly and quickly to calm the markets, while the ЕСВ was more cautious in managing monetary policy? The aim of this paper is to perform a comparative analysis of the management of the interest rates and other monetary policy measures undertaken by the European Central Bank and the Federal Reserve during the economic crisis, as well as to understand the emergence of the ECB's authority within the European Union's economic governance model since 2011.
Although both, the Federal Reserve and the European Central Bank, managed the monetary policy of their particular area, they are institutions that differ not only in its origins, but also (and mainly) on their objectives, and therefore, the effects of their actions are different. The Fed was founded before the $\mathrm{ECB}$, and has a much longer tradition of facing the negative effects of crises. Moreover, endowed with a broader objective than that of the European Central Bank, it performs in very close coordination with us government authorities. The Fed has a common goal with the us government, which is to be a unique interlocutor when it comes to implementing its policy. Instead, the есв is a recent institution established over time, as a result of the European Economic and Monetary Union, on the basis of the Maastricht Treaty with one specific objective: market price stability. However, that goal has proven to be insufficient to cope with the economic crisis and the complex environment of the nineteen $\mathrm{EU}$ member states. The Eu being very heterogeneous, where each one has its own voice and presents different realities.

Therefore, among this comparative analysis and limiting its time frame to the 20072014 period, we will firstly examine the different actions the ЕСB and the Federal Reserve have taken since the beginning of the crisis. Secondly, assuming that the characteristics and the environments of each of these central banks were different (due to their mandates and the systems of economic governance in which they operate), we will evaluate the reasons and factors that have marked the behaviour, timing and scope of their interventions. 
On the other hand, this study aims to help to understand the new situation of the European Central Bank, the changes in its context, as well as the emergence of its authority within the European Union's economic governance model since 2011. This is due to the assumption of new functions related to the supervision of the EFS and the emergence of the $\mathrm{ECB}$ as a more credible body in the EU (according to the Eurobarometer 2014). Finally, we will outline the conclusions, which will reflect on the future of Eu institutions, the features and the power they need to be given to fulfil their objectives within the European Union.

\section{THE PERFORMANCE OF THE ECONOMIC AND POLITICAL AUTHORITIES. THE PARTICULAR ROLE OF THE FEDERAL RESERVE AND THE EUROPEAN CENTRAL BANK}

After the end of the Iraq war in 2003, economic growth in the United States of America and Europe had been accompanied by a continued increase of interest rates. The American interest rates, between 2004 and 2006, increased from $1 \%$ to $5.25 \%$ (Figure 1 ), and remained stable at this level until August 2007. In the euro zone the ЕСв increased them stepwise since early 2006 (when the interest rates stood at 2\%) to the highpoint of $4.25 \%$ in July 2008 (Figure 1). Whether the management of monetary policy pursued by the central banks before the crisis was correct or not, will not be part of this analysis. However, since its beginning, there have been numerous studies examining the role of central banks, mainly the Fed and the есв (Diamond and Raján, 2009; Baldwin, 2009; González
Páramo, 2011) in relation to the high rates of economic growth and low interest rates in the short and long term dynamics, as well as their impact on the accumulation of risks in the financial system.

Beyond these considerations, between 2004 and 2006, subprime loans (mortgages linked to weak borrowers) in the United States of America exceeded $40 \%$ of the total, becoming contracted at a variable rate and indexed at the central bank rate. According to the International Monetary Fund, the number of mortgages had doubled since 1996. The housing prices, which had already started to fall a year before (in early 2007), began to suffer a steeper decline. In February 2006, the Federal Reserve began to estimate loss data for bankruptcies of mortgage banks, still far from the scale of figures from April 2007. Since July 2007 , the global stock markets have shown increasing volatility fluctuations. According to the statements of Ben Bernanke (then chairman of the Fed) in July 2007, the Federal Reserve estimated that the subprime crisis in the United States of America could be valued at more than 100 billion dollars and influenced not only the American markets, but also the European, by the interplay of private debt markets (CNNExpansión, July 19, 2007). Concurrently, in the summer of 2007 , the record of the Dow Jones Index surpassed 14,000 and the global stock markets began to show signs of exhaustion.

As the scope of the risks that entities had taken in the form of by-products was unknown, the uncertainty and changing estimated figures generated a crisis of confidence among the banks themselves. The suspicion 
spread very quickly, affecting not only the value of shares of funds involved in real estate (whether they were solvent or not), but also the value of the shares of banking groups. The monetary crisis evolved in to the stock market crash, primarily affecting North America and Europe, and later Asia, as well. Policymakers then began to act to alleviate the liquidity crisis. On August 17, the Fed reduced interest rates half a percentage point and issued early warnings about the general economic outlook regarding the extension of the banking crisis (El Mundo, 2007).

Although in August 2007 the size of the liquidity problems and solvency of the financial institutions were unknown, the central banks began to take steps to secure access to those entities to finance from the international markets. Therefore, each central bank (based on its own characteristics and tools at its disposal) intervened in the markets in order to ease tensions related to obtaining market liquidity and to restore confidence among the institutions themselves, which was the main reason why the credit flow had been reduced.

The role of central banks proved decisive, but government authorities also played an important role in the management of the economic crisis by supporting measures taken by those responsible for monetary policy. At the same time, the economic and political authorities intervened in the economy and social life to maintain the solvency of financial institutions and restore confidence between them and to calm the stock market turmoil and reassure depositors' savings (Noeth and
Sengupta, 2012). Therefore, all those measures had been in essence technical, but policy and legal initiatives were also decisive to limit the risks and support the actions of central banks with mandatory measures (Hernández de Cos, 2010). Thus, in this study we will focus on the actions taken by the Federal Reserve and the European Central Bank. However, the wider scope of those interventions cannot be understood without analysing the political measures introduced by the us congress, Eu institutions and national governments. Furthermore, since the crisis was a global phenomenon and it has affected many different structures of citizens' lives, the answers turned out to be exhaustive and coordinated not only between national, but also international economic and political agents.

Despite eight years of interventions from economic and political authorities and the improvement in some economic data, the macroeconomic variables are still showing signs of weakness and the risks seem to remain. According to the IMF Global Financial Stability Report (April 2015), it is the euro zone where the economic crisis has led to an institutional recession and has increased the model of integration. Therefore, we examine measures taken by the Federal Reserve, underpinned by the actions of us governmental institutions. Secondly, we analyse the solutions that have been implemented by the ECB, the EU institutions and the governments of member states. Finally, we proceed with a comparative analysis of the Fed's and Есв's management of monetary policy. 


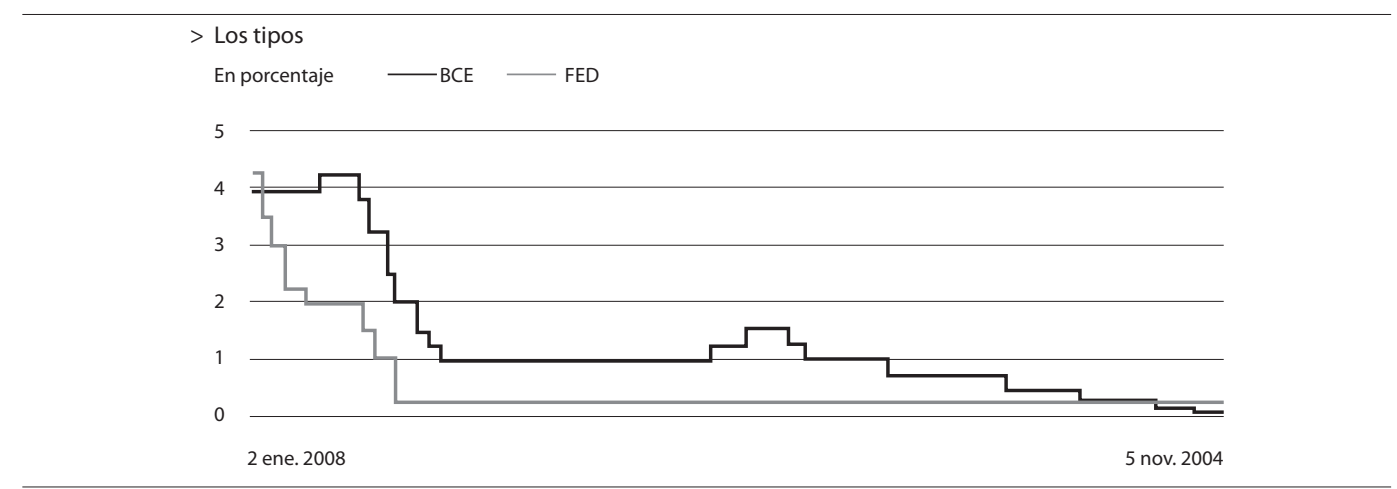

Source: http://www.coleconomistes.cat/ASP/RESUMSPREMSA/Expansion10112014_1.pdf

THE FEDERAL RESERVE'S AND THE EUROPEAN CENTRAL BANK'S PERFORMANCE DURING THE CRISIS

Since the beginning of the crisis, the measures undertaken by the Federal Reserve were reflected in the management of its interest rates and the changes in its balance sheet. The Fed's interventions, especially when compared with other central banks, were swift in action. While the first clear signs of the liquidity crisis and the difficulties of financial institutions to remain financed appeared in June 2007, in July of the same year the Federal Reserve (in coordination with other central banks such as the Есв and the Bank of England) intervened in the markets by pumping liquidity in to the system. A month later, its interest rates were lowered for the first time.

These early issues, which had been classified as liquidity problems of some American banks, transferred to Europe in September 2007. Northern Rock (United Kingdom) became the first English entity rescued by the Bank of England due to liquidity problems. The same month the Organisation for
Economic Co-operation and Development (OECD) started to lower economic growth forecasts for the G7 (oECD Economic Outlook, no 82, December 2007). The Federal Reserve's functions included promoting full employment, economic growth and price stability, but also to maintain the stability and contain risks that may arise in the financial system. It undertook different strategies during the first year of its actions, which included cutting interest rates and injecting liquidity through open market operations. As an example, the Fed lowered the interest rates to $4.75 \%$ a fortnight after doing it for the first time.

Moreover, a large number of negative corporate news stories forced the central banks to proceed with another liquidity injection. In late October, the Fed dropped its interest rates to $4.5 \%$. November and December issued more unfavourable business and banking news, which encouraged central banks to continue injecting liquidity into the market. In December, the Federal Reserve lowered its interest rates further to $4.25 \%$. In January 2008, it was reduced by another three-quarters 
of a point (to $3.5 \%$ ), placing them (at that time) below the Есв rate.

Based on Ben Bernanke's recommendations about the need for fiscal stimulus, the us Congress reached an agreement on tax relief and tax cuts to revive the economy (Blinder and Zandi, 2010). A week after the latest interest rate cut, the Federal Reserve placed it at 3\%. As growth forecasts continued to shrink under poor business prospects, in March 2008, the Federal Reserve reduced its rates to $2.25 \%$. Meanwhile, central banks continued to pour liquidity into the financial system without achieving its aim to calm the turmoil and negative business expectations. In April 2008, the International Monetary Fund acknowledged that the United States of America was likely to enter a recession. At the same time, central banks continued to act together to inject liquidity into the system (it was the ninth intervention in the case of the Fed).

In June 2008, the Fed auctioned 75 billion dollars in loans to help entities with credit problems and the us government continued to support troubled banks; one example was the nationalisation of Fannie Mae and Freddie Mac (Granell Trias, 2009). Furthermore, on July 30, 2008, the us House of Representatives approved a housing rescue plan worth 300 billion dollars. In August, the Federal Reserve auctioned another 25 billion dollars in loans. In September 2008, the Lehman Brothers bankruptcy and the purchase of Merrill Lynch by Bank of America became a clear turning point of the crisis. The same month, the Fed and the current us government nationalised the world's largest insurer, AIG.
The described situation has exposed the need of governmental action to be not only more coordinated, but also much stricter. In November 2008, due to the dimensions of the crisis and its depth in the real economy (as evidenced by data the IMF reported the same month), the G20 met in Washington to discuss the problems that were threatening the global economy. Additionally, the FsB (Financial Stability Board) was created. Its aim was to analyse the global changes that had to be made in relation to the international financial system (Tobias, 2013). Even if the Washington meeting cannot be defined as a new Bretton Woods, it had a major impact on the future reforms that were taken later on. It marked a new philosophy and recognised that existing risks were global. It also underlined the need of acting jointly on changing the regulation and supervision scheme of the international financial system. In the same month, with the objective of generating more liquidity in the markets (by purchasing financial assets) the Fed announced the beginning of the QE (Quantitative easing) programme. After the Washington meeting, the support provided by international financial institutions (particularly the International Monetary Fund) was strengthened, while credit facilities began to be implemented.

Due to the escalation of the crisis, in December 2008, the us government (at the behest of the president of the Federal Reserve) doubled its public debt by carrying out a 700 billion dollar bailout to purchase toxic assets with the notion of reselling them once the situation was stable. The aim of that measure, combined with other actions, was to 
generate greater confidence for depositors and taxpayers. The deposit insurance limit, previously up to 100,000 dollars, was increased to 250,000 dollars (Granell Trias, 2009). In March 2009, us Treasury Secretary (Timothy Geithner) also announced the creation of public-private partnerships. Popularly called bad banks, these entities were established to acquire loans and toxic securities in order to sell them on when more favourable conditions existed.

Therefore, two sets of technical measures were implemented by the central banks. The Fed lowered its interest rates nine times since 2007 and chose not to raise them at any point during the same period of time. Since January 2009 , it placed them at $0.05 \%$. At this point, the Fed's interest rates remained in the range of $0-0.25 \%$. Both measures had a direct impact on monetary policy. Due to the escalation of the crisis in late 2008, the Federal Reserve lost its leeway for further action in terms of using interest rates as a monetary policy measure. Since 2009, it undertook another set of measures, in the form of Quantitative
Easing. Its first phase, applied from March 2009 to March 2010, had a global cost of 600 billion dollars and was complemented with two other phases. The second one, from November 2010 to September 2011, which received a total amount of 600 billion dollars, and the third one from September 2012 to October 2014. Although the liquidity injection has been declining gradually throughout 2014, all together, the QE phases increased the Fed's balance to 4 trillion (Figure 2).

The arrival of Barack Obama to the White House in January 2009 facilitated the public intervention plan and the implementation of the first tranche of QE. Later on, there was a G20 meeting, celebrated in London in April 2009, to discuss the current global situation, as well as to create a new schedule to restructure the financial system's supervision and regulation methods. Much more effective than the Washington conference, it established the types of measures to be implemented by the G20 countries and initiated changes in the European Union's economic governance model (implemented since 2011).

FIGURE 2. ECB BALANCE (TRILLIONS OF EUROS) / FED BALANCE (TRILLIONS OF DOLLARS)

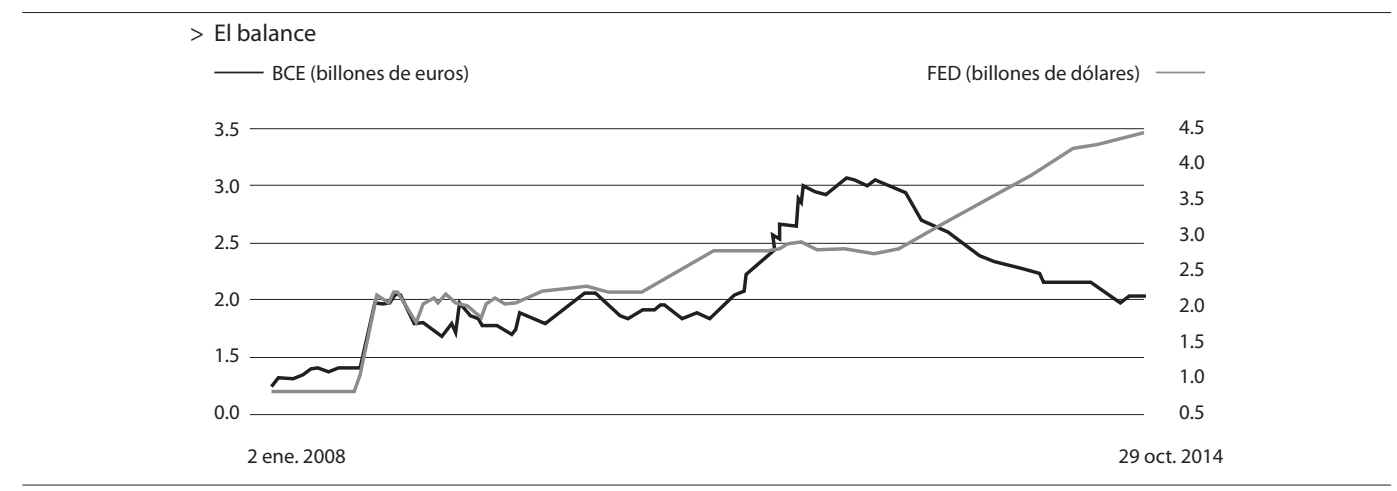

Source: http://www.coleconomistes.cat/ASP/RESUMSPREMSA/Expansion10112014_1.pdf 
Therefore, between 2007 (the beginning of the liquidity crisis) and 2009, open market operations and the management of interest rates became the main measures to complement government actions. However, from 2009 , as we have seen before, due to the escalation of the crisis, the Federal Reserve's ability to employ the interest rates as a reactivating measure vanished. All those new measures (QE, the establishment of the bad banks and other legal solutions) were also supplemented with FSB actions, all under the hypothesis of global risks pressure and the need of international coordination between different actors, states and/or financial institutions.

The coordination of the Fed's monetary policies and the ones pursued by government authorities has been key for the outcomes of these economic stimuli. The agility of the us central bank has been possible thanks to its more ambitious goals and the existence of a single government interlocutor to implement those goals. However, the European Central Bank, the mandate of the European Bank, the peculiarity of the European System of Central Banks and the enormous complexity of the European macroeconomic scenarios arising in the global economic context, defined the range of its capability in tackling the effects of the crisis. Furthermore, the limitations of the ECB's monetary policy mandate, its dependence on member states in the field of application of tax policies and assumptions to act, as well as the lack of a single EU government, restricted its leeway.

Since mid-2007, the Есв acted through open market operations, but did not change its interest rates. In early October 2008, due to the dimension that the crisis was taking, the Presidents of France, Germany, Italy and Great Britain gathered in Paris at an emergency meeting. A few days later, the interest rates of the major central banks were reduced in a joint operation to prevent the financial crisis from turning into a recession. It was the first time during the crisis that the ЕСв lowered its interest rates, to $3.75 \%$. The following day Wall Street registered a major collapse of stock markets, the first since 1987. Between October 2008 and July 2009, the есв reduced its interest rates eight times (from $4.25 \%$ to $1 \%$ in May 2009). In July 2011, it increased them again to $1.5 \%$ due to the fear of inflationary pressures. In December 2009, the European Central Bank lowered its interest rates to $1 \%$, reducing them gradually to $0.05 \%$ (September 2014).

'Still, based on its broad security assets system and by introducing massive liquidity into the system, the European Central Bank reacted in a steeper way than other central banks, taking advantage of entity instruments (González-Páramo, 2012, pp. 90-91). Through such measures, based on facilitating adjustment operations and other regular monetary policy operations, the ЕCB tried to eliminate mistrust and possible paralysis of the interbank market caused by the insolvency of Lehman Brothers. Thus, the ЕСв has not only acquired a crucial role in the context of the interbank market (becoming a safe haven label for deficit entities), but also did so without having to change its operational framework significantly. Moreover, it introduced onto its balance sheet the operations formerly executed by financial intermediaries, reduced 
the interbank market and executed a role of guarantor of last resort.

Additionally, in order to improve its results, the ECB also applied some extraordinary measures. In May 2009, it proceeded with the acquisition of cover bonds ( 60 billion euros) to encourage the liquidity of the partially paralyzed market segment responsible for providing funds to banks (Ayuso and Malo de Molina, 2011, pp. 54). Secondly, it implemented some temporary configuration changes in the long-term refinancing operation (LTRO). Those expansionary and unconventional measures, implemented (in its new form) in December 2011 and in February 2012, totalled around 1 trillion euros (National Bureau of Economic Research, 2011). It provided a fixed rate (1\%), had no quantity limit, and disposed of the extended term (from three months to three years). Among other introduced modifications, the extension of the range of eligible collaterals and the moderation of the admission criteria (Malo de Molina, 2013, pp. 116) were also found.

The Washington and London meetings, held in 2008 and 2009 respectively, as well as the Laroisière report (2009) gave way to the creation of a European System of Financial Supervision (esfs). That is to say, the European Union's particular network (with the European Central Bank partial participation) to promote the system's transparency, to exercise solvency control over the entities and to create a small and medium enterprises protection mechanism (Puente, 2013). However, because of its insufficiency and further banking union needs, some modifications were needed.
In addition, the complexity of the crisis forced the member states to redefine the Eu's supervision and economic governance system, putting special emphasis on the euro zone. The establishment of various mechanisms and modifications carried out under the EU institutional organisation chart have strengthened the European Central Bank's role in the community context. The ECB, involved in the design and implementation of the new system of European economic governance and in limiting the negative effects of the economic crisis, was a guarantor for the price stability objective and inclusion in the whole reform process, as well as in the adjustments applied by different member states. In each case, it supported faster consolidation, the broader strengthening of the national banking systems and the establishment of a new framework for macroeconomic surveillance.

The inadequacy of used mechanisms, the worsening of the sovereign debt crisis within the euro zone (especially the Greek situation), the operational miscarriage of the European Financial Stability Facility and the risk of failure for correct monetary policy transfer browbeat the European Central Bank into two covered bank bonds purchase programs (the first one, already mentioned before, applied in May 2009 and the second one enforced in October 2011 for a total value of 100 billion euros) and the Securities Markets Programme (sMP) implementation. Through the last one, the всв bought bonds of member states with greater financial pressure (Greece, Spain, Portugal, Ireland, and Italy). The risk premium level was the only criteria to be contemplated, while the emitter conditions, the 
terms and/or the interest rates risk have not been considered. Moreover, even though the indirect debt monetisation entailed a break with the spirit of Articles 123 and 125 of its Statute, the Есв sought to please the liquidity needs of its recipients and to influence their spending decisions. However, the euro zone's difficulties obliged the Eu's central bank not only to extend the SMP, but also to take a number of additional measures in order to alleviate the crisis.

Fourth, the dangerous summer that Spain lived in 2012, the critical economic situation of the Italian economy and the possible breakup of the euro prompted the president of the Есв to deliver on July 26 of this year historical statements on safeguarding the stability of the euro area. Because of this situation, the European Central Bank activated the Outright Monetary Transactions (омт) through which it sought to settle financial stability within the euro zone. The омт, by request of a member country, would begin the process of buying the government debt of these states (Cour-Thimann and Winkler, 2012: 5). Firstly, those which have been previously rescued by the European Financial Stability Facility or the European Stability Mechanism. And secondly, those who met the Memorandum of Understanding agreement and thirdly, those member states which also recovered the ability to place on the market its 10-year bonds. Like the Programme for the Securities Markets, the Monetary Operations Purchase would also be neutralised by the liquidity adjustment operations in order to avoid potential inflation. For now, in relation to its implementation, the only countries able to benefit from this rescue activity were Ireland and Portugal. However, its close compliance, improving markets and falling risk premium in target countries caused the OMT not to enter into force until 2012.

Furthermore, the publication of the report Towards a Genuine Economic and Monetary Union prepared by the presidents of the European Council, the European Commission, the Eurogroup and the European Central Bank and the subsequent report by Herman Van Rompuy was a clear impetus for future completion of the EMU. Through a process of negotiation and legislation, developed between 2012 and 2013, it was decided to establish a banking union community with the aim of strengthening the structure of the Economic and Monetary Union of the EU and to limit potential financial contagion between different member states. Based on two pillars, the Single Supervisory Mechanism (MUS) and the Single Resolution Mechanism (MUR), its structure has been further strengthened by the Harmonised Deposit Guarantee Scheme and is under a single system. Its main objective is to ensure the soundness of the banking system and the integration of the euro zone, and to reinforce its stability and financial integrity. Thanks to the MUs, from November 2014, the ЕСв became a single banking supervisor acquiring a number of new functions. Since then, it directly evaluates the financial viability of the 128 banks in a systemic manner and 3,500 entities indirectly. Meanwhile, through the MUR, member countries also established a system for resolving entities in the euro area with liquidity problems. Single Fund supported the resolution; the Single Settlement 
Mechanism seeks to minimise the costs of potential bank failures.

Finally, in late 2014 the European Central Bank adopted two new long-term refinancing operations (TLTRO) in order to grant new loans and limit the compliance of previously applied programs of the same nature (Bank of Spain 2014, pp. 19). It also launched programs for simple guaranteed bank bonds and securities from securitisations totalling 40 billion euros. For the purchase of private debt they acted not only in the primary markets, but also secondary.

Still, the depletion of the interest rates as a monetary policy instrument because of its approach to zero (zero lower bound) in September 2014 limited the effect of the relaxation of monetary conditions. The lack of effectiveness of the actions implemented on the balance sheet of the European Central Bank and the goal of price stability in the medium term led to the expansion of its activities with the implementation of quantitative easing (QE). Through this unconventional measure, from March 9, 2015, the ЕСB acquired the debt of public entities of the member states, worth 60 billion euros per month. Additionally, the purchase of bonds of up to 30 years even with negative interest (maximum $0.2 \%$ ) proceeded. It was expected that this activity, conducted in secondary markets, would not just level the interest rates in the long term by giving a boost to the economy in order to reactivate it, but also lower the risk premium of recipient countries and encourage investment as well as credit flow to the real economy of the eurozone. Moreover, while the total budget of the QE range is about 1.14 billion euros, if necessary, possible extension is not ruled out beyond September 2016.

In summary, there has been a wide variety of monetary policy management strategies. Today we can say that they even show disparity and contradiction. While the Fed withdrew the stimulus through the end of the QE plan in October 2014, the Есв began to implement an expansionary monetary policy through the European QE plan in early 2015. In the medium term, the Есв's expansionary policy could lead to a devaluation of the euro and create a movement of capital to the us.

During the crisis, the Fed opted to use liquidity and lower the interest rates from August 2007 and to purchase toxic assets from the market (like other central banks, such as the Bank of England) from 2008. However, the ЕСв acted like a bank by injecting market liquidity. Likewise and according to its mandate, when inflationary pressures were pointed out, it cut interest rates in October 2008. However, after 2009, it was unable to use interest rates as a tool of monetary policy and it was necessary to implement other measures. In some cases, it attempted to circumvent regulation that bars governments and other funding, such as the role of the single banking supervisor on the grounds of art. 127 TFEU (Treaty on the Functioning of the EU) in order to avoid the reform of the treaty and therefore unanimity.

\section{THE REASONS FOR THE DIFFERENCE IN BEHAVIOUR} BY THE FEDERAL RESERVE AND THE ECB

The Federal Reserve and the есв have been entrusted with the management of monetary 
policy; however, the behaviour of the two central banks differs in several ways:

Firstly, the liquidity crisis had its origin in the us but it spread rapidly, resulting in a crisis of solvency of financial institutions, in a stock market crisis and ultimately into a global economic crisis. However, the early symptoms began in early 2007 , and focused on the us housing market. On the one hand, it is consistent that the Federal Reserve was the first central bank to act because the crisis mainly affected the North American markets in the beginning. Moreover, financial markets were deeply interrelated and, as the president of the Federal Reserve Ben Bernanke warned in the summer of 2007, the extension of us risks to other markets was inevitable. Therefore, the different interventions coordinated by the central banks were to improve liquidity in the system through open market operations. The FSB, at their meeting in Washington in November 2008, stressed that the risks were global and that cooperation between States was necessary to prevent them.

'Secondly, and the key to the various interventions is the difference in mandate between the Federal Reserve and the есв. The European Central Bank, created on June 1, 1998, replaced the European Monetary Institute (ЕмI). That is, the interim body responsible for strengthening ties between the central banks of the member states and their respective monetary policies, leading to the future constitution of the European System of Central Banks (ЕSСB) in order to manage the process of monetary union of the EU. Currently the ЕАСв comprises the ЕСв (the cornerstone) and the national central banks
(NCBs) of all member states. It also contains in its framework a temporary monetary authority of the euro zone. According to Article 127 of the Treaty on the Functioning of the European Union the primary objective of the European System of Central Banks (and also the ЕСв), responsible for the design and implementation of monetary policy in the euro area is to maintain price stability below $2 \%$. In addition, it should facilitate compliance with the general Eu objectives described in Article 3 of the Maastricht Treaty to strengthen the performance of Eu policies in order to ensure full employment, non-inflation and balanced economic growth, as it will operate on the principle of an open market economy with free competition. Still, this contribution will be of secondary importance against its purpose relative to inflation.

Undoubtedly, the subordination mentioned was the main factor that influenced the activity of the European Central Bank over the crisis, explaining its delay in following the footsteps of the us Federal Reserve and balancing the extent of its activity and the implementation of characteristic measures of a moderate economic policy. As for the instruments of monetary policy of the European Central Bank, they are closely linked to their functions. In addition to maintaining price stability, the ЕСв seeks to control interest rates and to manage short-term liquidity in the money market. It also evaluates financial market conditions in order to preserve its stability and integration. For these purposes, it has standing facilities, open market operations and a reserve requirements mechanism (Cecchetti and O'Sullivan, 2003, pp. 33-34). 
Still, the virulence of the macroeconomic situation forced the European Central Bank to implement a series of measures unconventional in character and to adapt amid the crisis to new functions not only in the context of monetary policy, but also in the context of financial supervision, increasing the flexibility of its scheme of action. Among the main extraordinary monetary tools, described above, temporary configuration changes, operations long-term refinancing, the Programme for the Securities Markets Programme, the Monetary Operations Purchase fund, ultimately leading to the approval (in September 2014) of quantitative expansion.

The organisational structure of the European System of Central Banks, the public, and their procedural legitimacy supported by the ЕSCB and the ЕСв, in addition to the ordinary legal regulation of the $\mathrm{EU}$, has also influenced the development of its performance in the years since the crisis, changing the effectiveness of its efforts. The inability to exercise a single speaker, the lack of completeness of the configuration of the Economic and Monetary Union and the heterogeneity of national scenarios in member countries were other key factors in this context.

With regard to the ECB's independence, because none of the agencies belonging to the ESCB may solicit or receive pressure from any EU institution or national government of the member states, the aim of this truly comprehensive condition remains in favour of price stability. In this way, financial mechanisms available to the ЕСв are isolated from the rest of the community mechanisms, ensuring a process of autonomous decision making that has functional independence and does not have strong community control over its actions. However, it was threatened by pressures from national governments, because the mandate of the European Central Bank was different from the objectives of the EU institutions and the States of the euro area. Additionally, the lack of adequate institutional solutions and the complexity of the scenarios of the crisis have shown that the member countries need different monetary policy responses. Thus, the existence of the nineteen different partners in the euro area that had significantly disparate problems hindered the articulation of a single monetary policy by the ECB, which was balancing effectiveness and inviting them to extend its mandate.

Furthermore, the establishment of the Federal Reserve was the result of a set of different causes from the case of the Еsсв. In particular, a series of bank panics in the early twentieth century, the losses of depositors, and the lack of a sufficiently flexible and stable us financial system led (based on the December 23, 1913 Federal Reserve Act) to the merger of all national banks and the creation of the Fed (Sprague, 1914, pp. 213-214). Its mandate, like the Есв, is to define and implement the monetary policy of the State, keeping interest rates at a moderate level over the long term and ensuring price stability. However, in the case of the Fed (unlike the ЕsCB), in order to keep inflation and growth, they have the same level of importance (Cecchetti and O'Sullivan, 2003, pp. 33). Also, the structure of the multidimensional character of the US, through which the interests of different regions, different groups (the public, traders and bankers), 
as well as public and private sectors are all organised, effectively facilitated the application of an efficient monetary policy response to the crisis, which was quickly implemented and consistent with the objectives set by the US government.

The Fed's goals are broader than those of the всв. The Fed is also responsible for controlling the rate of unemployment, so the variety of tools at its disposal is much broader, such as gathering measures of monetary, fiscal and financial stability. The Federal Reserve also acts as supervisor and regulator of banks in order to safeguard the stability of the banking and financial system, it dictates the credit rights of consumers and provides financial services to depository institutions of the government and official foreign bodies. Unlike the ЕСв, the Fed was a guarantor of last resort since the beginning of the crisis, which greatly facilitated its task and increased the effectiveness of its measures. That is, the difference in strategy explains the differences mainly in relation to interest rates. The Federal Reserve lowering the interest rates is upheld in its mandate to stabilise the financial system. Unlike the ECB, which has a priority mandate of inflation control, so that if it wanted to act in accordance with its objectives it should use inflationary pressures to justify its intervention (see figure 3).

The problem is that what was asked of the ЕСв by the states during the crisis was a more agile and closer performance in secondary endpoints, according to its statutes, to boost the economy with expansionary policies that encourage growth and job creation. Therefore, the Есв has gained new features throughout the crisis and has consolidated its mandate. However, these functions are not covered by its statutes. That is, it has no legal basis in other similar circumstances that allow it to act without control with a mandate of price stability as a priority.

Moreover, the ECB and the Fed could no longer use interest rates as a management tool of monetary policy after 2009, because these were near zero. Therefore, they had to articulate a series of measures in the case of the Есв involving the acquisition of new

FIGURE 3. IPC EURO ZONE / USA (IN PERCENTAGE)

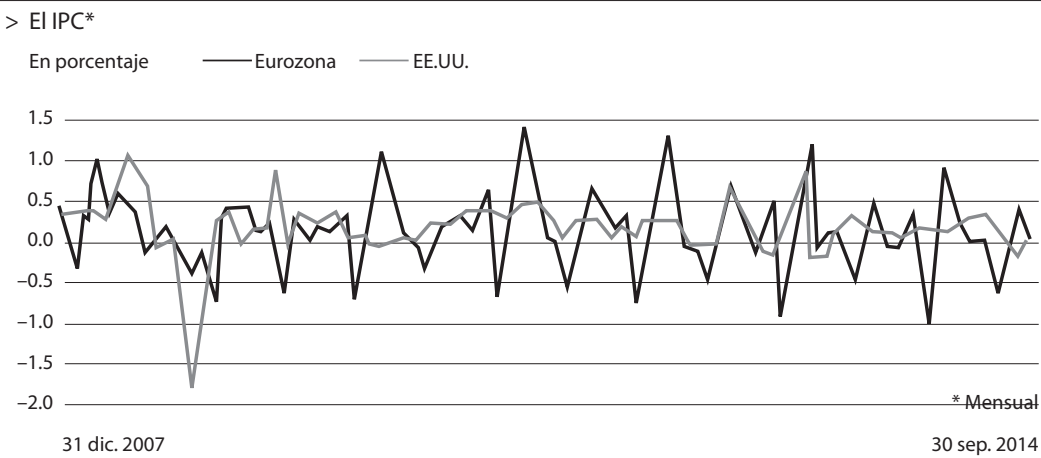

Source: http://www.coleconomistes.cat/ASP/RESUMSPREMSA/Expansion10112014_1.pdf 
capabilities, not only as a guarantor of last resort, but also completing its objectives as sole banking supervisor.

While both central banks are independent, the European Central Bank stands as the most independent central bank in the world. The Federal Reserve is autonomous in theory, but less so in practice. To identify the origins of the ЕСв we must go back to the negotiations of the Treaty of Maastricht where the philosophy of the so-called economist group triumphed over the so-called monetarist group. The monetarist group (led by Germany and Luxembourg in particular) wanted a politically independent central bank, while the economist group (led by France, Belgium and Italy) preferred a more political central bank, with more challenges and a structure linked to the objectives of the Community institutions. The result is that there is close coordination between the policies of the us government and the actions of the Fed. However, the ECB's objectives and member states have a different hierarchy. Therefore, during the crisis we have seen monetary policy measures which collided with the fiscal policies of some member states that needed priority economic growth and employment over the inflationary pressures, such as the rise in interest rates in July 2011. Moreover, the Fed does not have the same degree of sovereignty that the European Central Bank has. It has accountability to Congress and must take any changes made by the Congress of the us in its statutes. That is, the opposite of the еsсв. In addition, the amplitude of measures that can be applied creates a scenario of potential risk to the independence of the Federal Reserve, a scenario that we observed in the context of the crisis, but impossible to rebuild in the case of the European System of Central Banks (Ayuso and Malo de Molina, 2011, p. 60).

Another important difference is that the Fed has had a single partner throughout the crisis to coordinate government policy. However, the Есв has nineteen different partners with different problems. It has great difficulty in articulating a single monetary policy for all its heterogeneous states. Both the different member states of the euro area and the different states of the US were affected unequally by the crisis. There is, however, a fundamental difference. The Federal Reserve is the central bank of a single country, despite all the differences that may exist between the various us states. The coordination of monetary policy comes from a single entity, a single government that directs actions in fiscal policy and a single government body that coordinates the funds. However, in the case of the Есв, the coordination of monetary policy with fiscal policy involves all eurozone members, who are different and unequal. The есв has no power to force them to act as it can only recommend guidelines. This plurality in the transmission of monetary policy causes delays in implementation. It is not only the very objectives that are implemented but also monetary policy that must be supported and coordinated with fiscal policy measures that work on an intergovernmental basis. It is apparent that as with the banking union, the states are not similar and therefore it is more difficult to get resources to implement all these measures. An example of this is the negotiation of the financing of the banking 
union. Among the main obstacles, the project has raised concerns regarding who and how the resources will be provided to help troubled banks. In the absence of a common treasury in the euro area, the search for funding to implement the banking union completely becomes a nineteen-sided political negotiation. The agility and consistency of monetary policy are diminished by national fiscal policies (Yiangou et al., 2013).

Despite these drawbacks and difficulties, the ECB is the Community institution that has gained power within the system of economic governance of the EU, not only in the case of financial banking supervision, but also in a position of de facto guarantor of last resource. Different studies have recently appeared analysing the rise of power from the perspective of the neo-functionalist and liberal intergovernmentalist theory (Chang, 2015). This is a starting point for analysing the future role the Есв will play and the implications it has for the whole of Eu institutions and the future of the Union (Schwarcer, 2012). Should we prioritise the interests of the member states or the interest of the $\mathrm{EU}$ as a super state?

\section{CONCLUSIONS}

Following the completion of this comparative analysis of the monetary policies of the Fed and the ЕСB during the 2007-2014 period, we have reached the following conclusions:

The monetary policy strategy of the ECB and the Federal Reserve during the crisis has been different and remains manifestly divergent and contradictory. While the Fed withdrew the stimulus plan of QE by the end of 2014, the ECB planned to implement its first phase in early 2015.

On the one hand, the US central bank and the eurozone acted in a coordinated manner in the management of open market operations by intervening in the markets to provide them with liquidity. The management of exchange rates was deferred. If the Fed lowered interest rates for the first time in August 2007, we had to wait until October 2008 for the Есв to do the same. This is due to several reasons. Firstly, the crisis originated in the us and it seems appropriate that the first bank to act was the Fed. However, financial markets are global and us risk soon spread to the rest of the international markets, which forced other central banks to act to protect their troubled markets.

Secondly, the mandate of the Federal Reserve is broader than the ЕСв and therefore relies on more assumptions when it comes to acting. The Fed has the objective of ensuring economic growth, full employment and moderate inflation, all with the same rank of importance. In addition to this, the Fed is responsible for controlling the stability of the financial system and supervising financial institutions. On the other hand, the Есв's mandate it is more limited. Before the crisis, controlling inflation within a limit of $2 \%$ on average was established as a priority. It also contributes to other objectives of the European Union and encourages economic growth and full employment. The problem is that there is a hierarchical relationship between its goals. Therefore, the Есв acted later than the Fed because inflation did not give it sufficient signals to intervene. That is, by relying on such 
legitimacy in procedure, the ECB delivered on that functionality. The problem was that the dimension of the crisis needed a broader intervention. The governments of the $\mathrm{EU}$ as a whole and the Community institutions gave priority to employment and economic growth, while the European Central Bank prioritised price stability. Although the reasoning justifying this hierarchy of objectives was intended to maintain the political independence of the European Central Bank (Institute for International Political Economy Berlin, 2014), it has revealed an inconsistency between the objectives of the ЕСв of a technical nature and objectives of the member states, which are more political. This sometimes caused opposing expansionary fiscal policies and instability in interest rates to curb inflation. This is due to the heterogeneity of the eurozone, different realities defended by the governments of the member states and a single monetary policy, equal for all. However, the need for the ЕСв to play a more active role has encouraged the ECB's responsibilities to be revised and expanded in some cases. The weakness of this is that they have not changed the ECB's responsibilities in the Treaties because this would require unanimity among the States of the European Union and would expand over time. This would also mean that the member states would have to lose some of their autonomy.

Thirdly, the Federal Reserve and the есв are defined as independent central banks. However, the есв's independence is further guaranteed by different instruments. At the beginning of the crisis, the ЕСВ acted under cover of that sovereignty. However, the need by States to extend its functions and to take a particular stance for economic growth and employment has demonstrated its political independence. The Federal Reserve has a theoretical independence, but in practice, there has been close coordination between the authorities of the Fed and the us government to support measures in monetary policy with other policies at government level.

Fourthly, the есв has had to act during the debate of the economic governance model of the Eu by which it is directly affected and which has been reformed during the economic crisis. That is, in addition to dealing with the economic difficulties there was widespread reform of the European structures of governance.

Fifthly, the ЕСв has nineteen partners and different organizations that manage monetary policy and this has created difficulties and lack of coordination between the ЕСв and that of the euro area. While Germany and other member states less affected by the crisis have opted for the ЕСв to pursue only its technical objectives and have followed a more austere fiscal policy, the Mediterranean countries have needed a more active role in managing an expansive policy. This meant that the ЕСв had to assume broader functions such as acting as a guarantor of last resort. The coordination of monetary policies of central banks and the actions of the political authorities have been crucial in helping to restore the confidence of the markets. Thus, for monetary policies and measures to be implemented swiftly and coherently with other policies, fiscal and wage policies, close coordination and an open dialogue between policy makers and political authorities is necessary. Therefore, central banks have a leading role, but have required 
government authorities to provide support to restore confidence in the financial system.

The есв has emerged as the Community institution that has gained more power. The functions entrusted regarding the application of monetary policy measures are broader, in terms of banking supervision, and as de facto guarantor of last resort. However, this role that the есв has acquired and that complements the system of economic governance of the $\mathrm{EU}$ has been well discussed by the member states, as it was not originally added to its statutory powers but through other legal means which are less clear. Discussions are still ongoing regarding the completion of the banking union and providing it with the functions exercised in its Statutes which are conferred to its acting procedural legitimacy. Therefore, the crisis has led to a reform of EU economic governance in which the European Central Bank has come to have increased power. However, it is still a system of economic governance with many weaknesses. The fundamental problem is that it lacks a complete model. In order to achieve this it is essential to have political negotiation, establish a plan of action to face the crisis and the provision of resources to implement the policies and regulate actions of institutions. In short, the balance of power between the states and the Union remains the main stumbling block in the progress of the integration process of the European Union. Political negotiations of member states are key to determining the future of economic governance in the Union and therefore its ability to face future challenges.

\section{REFERENCES}

Ayuso, J. y Malo de Molina, J. L. (2011). El papel de los Bancos centrales durante la crisis financiera. Papeles de la Fundación, 42, 49-64.

Baldwin, R. (2009). The Great Trade Collapse: Causes, Consequences and Prospects. London: Voxeu y Centre for Economic Policy Research.

Bank of Spain (2015). La ampliación de los programas de compra de activos del BCE. Retriever from http://www.bde.es/f/webbde/SES/Secciones/ Publicaciones/InformesBoletinesRevistas/BoletinEconomico/15/Mar/Fich/be1503.pdf

Blinder, A. and Zandi, M. (2010). Un estímulo bien empleado. Finanzas y desarrollo. Retriever from https://www.imf.org/external/pubs/ft/fandd/ spa/2010/12/pdf/blinder.pdf

Cecchetti, S. and O'Sullivan, R. (2003). The European Central Bank and the Federal Reserve. Oxford Review of Economic Policy, 19 (1), 30-43.

Chang, M. (2015). The rising power of the всв: the case of the single supervisory mechanism. Paper prepared for the biennial conference of the European Union Studies Association, 5-7. Retriever from https://eustudies.org/conference/papers/ download/24

CNNExpansión (2007). Inflación, el principal temor de la fed. Retriever from http://www.cnnexpansion. com/economia/2007/7/19/inflacion-el-principal-temor-de-la-fed

Cour-Thimann, P. and Winkler, B. (2012). The есв's non-standard monetary policy measures: the role of institutional factors and financial structure. Oxford Review of Economic Policy, 28, 765-803. De Grauwe, P. (2014). Economics of the Monetary Union. Oxford: Oxford University Press 
Diamond, D. y Rajan, R. (2009). The Credit Crisis: Conjectures about Causes and Remedies. American Economic Review, 99 (2).

Dyson, K. y Featherstone, K. (1999). The road to Maastricht. Negotiating Economic and Monetary Union. Oxford: Oxford University Press

El Mundo (2007). Turbulencias financieras. EE.UU. baja el precio del dinero ante el miedo a una recesión. Retriever from http://www.elmundo. es/papel/2007/08/18/

European Central Bank (2010). Asset Price bubbles and monetary policy revisited. Retriever from https:/www.ecb.europa.eu/pub/pdf/other/art1_ mb201011en_pp71-83en.pdf

European Council (2012). Towards a Genuine Economic and Monetary Union. Retriever from http:// www.consilium.europa.eu/uedocs/cms_Data/ docs/pressdata/en/ec/134069.pdf

G20 (s.f.). Declaration of the Summit on Financial Markets and the World Economy. Retriever from http://www.g20.utoronto.ca/2008/2008 declaration $1115 . \mathrm{html}$

González-Páramo, J. M. (2012). La gestión del Banco Central Europeo ante la crisis. Revista de Economía Mundial, 30, 83-102.

Granell Trias, F. (2009). Las medidas contra la crisis, sus problemas y su impacto intergeneracional. La primera crisis global: procesos, consecuencias y medidas. ICE (850), 57-72.

Hernández de Cos, P. (2010). El papel de la politica fiscal en la crisis económica. Presupuesto y Gasto público, 59. Instituto de Estudios Fiscales.

Institute for International Political Economy Berlin (2014). Policy-making of the European Central Bank during the crisis: Do personalities matter? Retriever from http://www.boeckler.de/ pdf/v_2014_10_30_basham_roland.pdf
International Monetary Fund (2015). Global Financial Stability Report. Retriever from https://www. imf.org/external/spanish/pubs/ft/gfsr/2015/01/ pdf/sums.pdf

Laroisière, J. (2009). The high-level group on financial supervision in EU. Retriever from http:// ec.europa.eu/finance/general-policy/docs/de_larosiere_report_en.pdf

Malo de Molina, J. L. (2013). La respuesta del Banco Central Europeo a la crisis. Banco de España. Boletín económico, 115-124.

National Bureau of Economic Research (2011). Monetary Policy Strategy: Lessons From The Crisis. Retriever from https:/www.imf.org/external/np/ seminars/eng/2011/res2/pdf/fm.pdf

Noeth, B. and Sengupta, R. (2012). Global European Banks and the Financial Crisis. Federal Reserve Bank of St. Louis Review, 457-481.

Organisation for Economic Co-operation and Development (OECD) (2007). OECD economic outlook 82. Retriever from http://biblioteca. hegoa.ehu.es/system/ebooks/16677/original/2. pdf? 1400066325

Puente Regidor, M. (2013). Hacia un nuevo modelo de supervisión y regulación financiera en la Unión Europea: retos y perspectivas (forthcoming book chapter). Toulouse: University of Toulouse.

Schwarzer, D. (2012). The Euro Area Crises, shifting power relations and institutional change in the European Union, Global Policy, 3, 28-41.

Sprague, O. M. W. (1914). The Federal Reserve Act of 1913. The Quarterly Journal of Economics, 28, 2, 213-254.

Tobias, A. (2013). Discussion of An Integrated Framework for Analyzing Multiple Financial Regulations. New York: Federal Reserve Bank of New York. Retriever from http://www.ijcb.org/journal/ ijcb13q0a7.pdf

OASIS, $\mathrm{N}^{\circ} 23 \cdot$ Enero-Junio 2016.pp. 147-167 
Treaty of Lisbon amending the Treaty on European Union and the Treaty establishing the European Community, signed in Lisbon, December 13, 2007. oJ C 306, 17.12.2007

Yiangou, J., O’Keeffe, M. and Glöckler, G. (2013). Tough Love: How the ECB's monetary financing prohibition pushes deeper Euro Area integration. Journal of European integration, 25 (3), 223-237. 